\title{
Prospect of Milicia excelsa (Welw.) C. Berg for Multi-Tree Species Agroforestry
}

\author{
Alfred Ossai Onefeli ${ }^{1 \Xi}$, Patrick Onyebuchi Agwu ${ }^{1}$ \\ 1 University of Ibadan, Faculty of Agriculture and Forestry, Department of Forest Resources Manage- \\ ment, Ibadan, Nigeria \\ $\varangle$ Corresponding author: e-mail: ftaxonomist@gmail.com
}

Citation:

ONEFELI AO, AGWU PO 2015 Prospect of Milicia excelsa (Welw.) C. Berg for Multi-Tree Species Agroforestry. South-east Eur for 6 (2): 249-256. DOI: http://dx.doi.org/10.15177/seefor.15-21

\section{Abstract}

Background and Purpose: The population of most of our economically indigenous tree species in Nigeria is declining. Human activities and agricultural practices have been the ultimate contributors to this decrease. In order to ameliorate the conflict between agriculture and forestry, agroforestry was introduced. However, most of the practiced agroforestry is based on single tree species. Agroforestry practiced using single tree species have been reported to be ecologically staggered and therefore it is pertinent that phytosociology of trees with agroforestry potential is studied in order to improve the sustainability of human livelihood.

Materials and Methods: This study was carried out in the University of Ibadan's campus forest. The data were collected on Milicia excelsa (Welw.) C. Berg by enumerating the tree species and also by identifying and enumerating the tree species associated with the subject tree (Milicia excelsa). Statistical analysis was done using percentages, Chi-square and charts.

Results: A total of 49 individual Milicia excelsa were encountered in the study area. The results show 31 woody tree species associated with Milicia excelsa. Of all the associates Azadirachta indica A.Juss. happened to be the best one, having an average distance of $5.4 \mathrm{~m}$ to the subject tree. The sex ratio of Milicia excelsa was discovered to be approximately 1:1.

Conclusions: Based on the obtained results of this research it may be concluded that Milicia excelsa has the prospect of being used in agroforestry in multi-tree species systems.

Keywords: phytosociology, sex ratio, biodiversity, conservation, Milicia excelsa 


\section{INTRODUCTION}

Agroforestry practices have considerable potential in solving some of Africa's main landuse problems [1-2] through provision of a wide range of tree products for domestic use or sale [3]. Agroforestry plays a significant role in increasing agricultural productivity by nutrient cycling, reducing soil erosion, improving soil fertility and enhancing farm income compared to conventional crop production [4-6]. Agroforestry can also potentially reduce deforestation while increasing food, fodder and fuelwood production $[5,6]$. The benefits of agroforestry practice include food and nutrition security, increased income and assets, improved land management [7]; it also creates environmental and management synergies [8].

Traditional agroforestry has been practiced for millennia by agrarian-based societies throughout the world [7]. The World Bank estimated that 1.2 billion people practice some form of agroforestry on their farms and in their communities [9]. Although agroforestry has been practiced by these farming communities for a long time, there is inadequate study about the ecological compatibility of the tree components.

The sustainability of any agroforestry practices depends largely not only on the compatibility of the agricultural crops with forest trees, but also on the effectiveness of the tree components vis-à-vis contribution to food crops' yield and soil management [10].

Over the years, many agroforestry practices embarked upon by rural farmers and agroforestry experts have been dominated by mono-specific tree components. Using one tree species in tandem with the agricultural crops has been previously preached against. However, this is based on the reason that single tree species have not been able to meet the need of people. This is also coupled with the fact that population of those who depend on agroforestry output for livelihood is geometrically increasing. This has not only led to the depletion and disappearance of many valuable trees through deforestation but has also aggravated food insecurity, especially in the rural areas. However, multi-tree-species agroforestry has been suggested [11-13] as a means of creating a more environmentally friendly system compared to the monospecific tree pattern. Practicing multi-treespecies agroforestry can also improve the sustainability of biodiversity, the production of good quality timber and non timber species, the control of pest and diseases and climate change amelioration. In order to identify the tree species compatible for a multi-tree-species agroforestry, the phytosociology of such trees needs to be studied. Due to lack of preassessment of the phytosociology of some socalled agroforestry trees, lots of agroforestry practices have been jeopardized. This is because some trees happened to inhibit the growth of other trees and agricultural crops growing around them [14].

Apart from the phytosociology, the reproductive ability of the tree species is also very important in determining the sustainability of the agroforestry. In many instances, the reproductive ability of any dioecious tree species is determined by sex ratio, which also in the long run affects its agroforestry potential. This study therefore examined the agroforestry potential of Milicia excelsa (Welw.) C.C. Berg in the University of Ibadan. According to Borokini et al. [15], the University of Ibadan houses the bulk of the $M$. excelsa in Ibadan because of more considerable level of protection from the tree felling on the campus. Milicia excelsa is commonly known as Iroko in Nigeria. Iroko as a member of the family Meliaceae is a windpollinated dioecious tree species, threatened by overuse and areal fragmentation with typically low density. Iroko is a large deciduous tree that reaches up to $50 \mathrm{~m}$ height and $4 \mathrm{~m}$ diameter at breast height (dbh), with high umbrellalike crown growing from a few thick branches [15]. It is native to tropical Africa, mostly West and East Africa. Currently, this species is categorized as one of the endangered valuable timber species under the International Union for Conservation of Nature (IUCN Red Data List). Some of the threats to this species include 
heavy exploitation, iroko gall (Phytolyma fusca Alibert, 1947) which attacks especially at an early growing stage, and an easy lost of seeds' viability. A number of countries have formulated policies toward its protection. For instance, it is protected by law in Ghana, Ivory Coast and Mozambique, while in Kenya, a Presidential ban on logging of indigenous timber was implemented in 1986.

Apart from the fruit production, male $M$. excelsa is different physiognomically from the female counterpart in terms of the crown position (Figure 1). On male trees, branches are more or less arranged in an orthotropic pattern, with an angle from lateral branches to the main stem below $90^{\circ}$, while on female trees branches are arranged in a plagiotropic position. In addition, female iroko produces lengthier and knot-free merchantable bole and this has undoubtedly made it more suitable for timber production than male. Presently, there is a lack of information on the phytosociology of indigenous trees with agroforestry potential. According to Zubair et al. [16], Milicia excelsa is one of the pioneer species mostly preferred on farmlands for agroforestry purposes. This is due to its positive effect on soil fertility, soil-nutrient cycling and exhibition of favourable interactions with crops [17]. Populations of Milicia excelsa in the natural forests have been in decline over the years, resulting in the fact that only areas which still have a considerable stands of Milicia excelsa are Universities' Forests, Strict nature reserves and cemeteries [15]. This therefore makes the present study important.
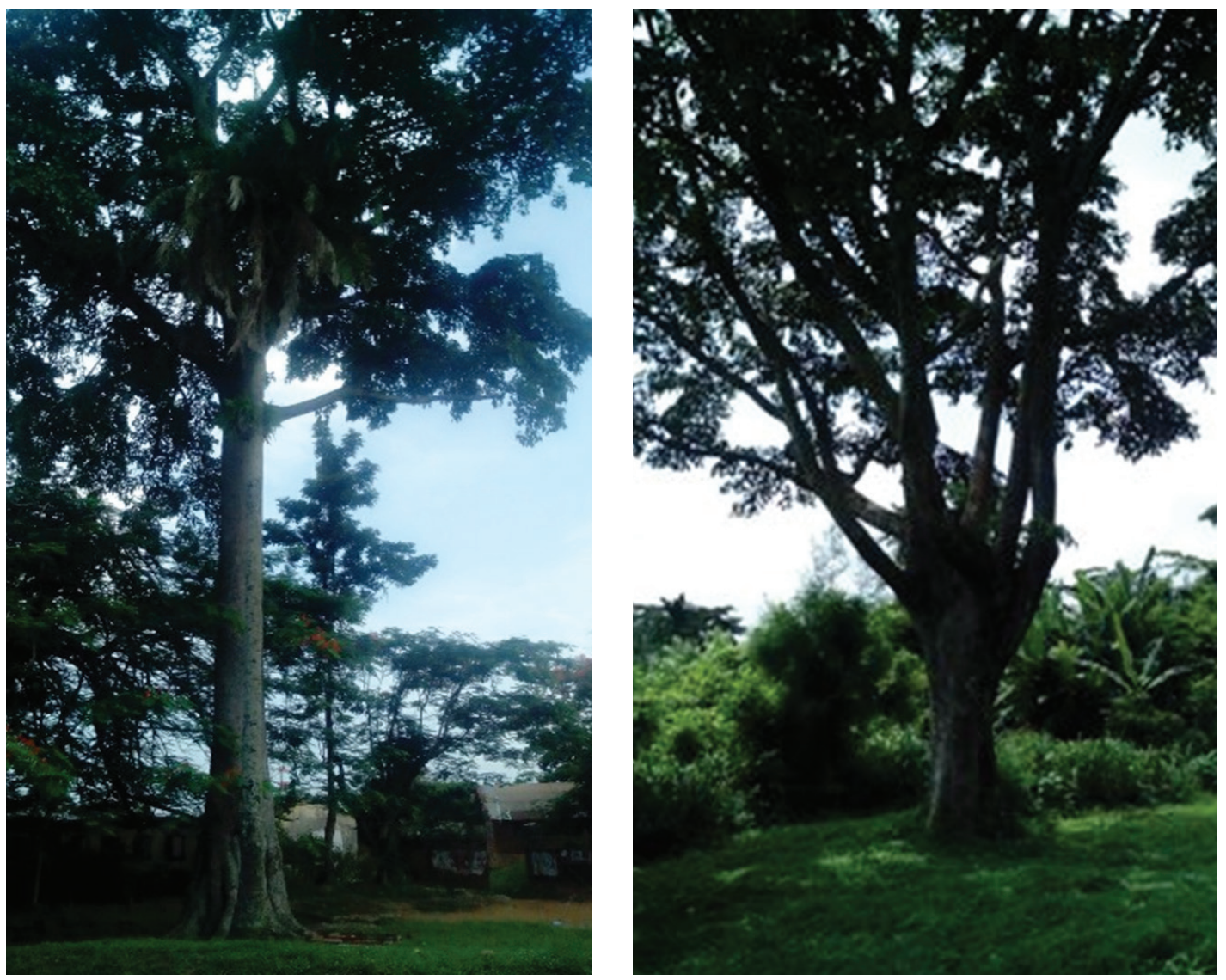

FIGURE 1. Female (left) and male (right) $M$. excelsa in the University of Ibadan 


\section{MATERIALS AND METHODS}

This study was carried out in the University of Ibadan's forests. These forests are located around the school's administrative and residential area. The University of Ibadan's campus is located north of Ibadan along Oyo road (latitude $7^{\circ} 28^{\prime} \mathrm{N}$, longitude $30^{\circ} 52^{\prime} \mathrm{N}$, altitude $277 \mathrm{~m}$ a.s.l.). The climate is the West Africa monsoon with dry and wet seasons. The dry season lasts usually from November through March and is characterized by dry cold wind of harmattan. The wet season usually lasts from April to October with occasional strong winds and thunderstorms. The annual rainfall in the area is $1258 \mathrm{~mm}-1437$ $\mathrm{mm}$ with mean daily temperature ranging from $22^{\circ} \mathrm{C}-31^{\circ} \mathrm{C}$. Soil type is ferric luvisols.

The collection of data was accomplished through identification, enumeration and measurement of distances between the subject tree ( $M$. excelsa) and its associates' woody tree species. The closer a woody tree species is to $M$. excelsa, the more associated is the species with the subject tree. To identify the tree species associated with the subject tree, a search radius method according to Sabiiti and Cobbina [18] was used. Crown diameter of the subject tree was measured using $50 \mathrm{~m}$ tape for the estimation of the search radius. An associate woody tree species is a single or multi-stemmed individual with a $\mathrm{dbh} \geq 10 \mathrm{~cm}$ located within the search radius of the subject tree [18]. Search radius (SR) is the distance from the subject tree within which all other trees are considered associate trees. It can be calculated as: $S R=7 / 4 \times C D$, where $C D$ is a crown diameter of the subject tree.

Data were analyzed using percentages, graphs and Chi-square test. Microsoft excel 2003 and IBM SPSS Statistics 20 are the statistical software used for the data analysis.

\section{RESULTS}

\section{Phytosociology of $M$. excelsa}

A total of 31 associated woody tree species with $M$. excelsa, belonging to 14 families (Table 1) were encountered in the study area. Of the entire tree species associated with $M$. excelsa, Azadirachta indica A.Juss happened to be the first associate, having an average distance of $5.4 \mathrm{~m}$ to the subject tree ( $M$. excelsa). Other tree species also closely associated with $M$. excelsa are Entandrophragma cylindricum (Sprague) Sprague, Trichilia heudelotii Planch. Ex Oliv., Elaeis guineensis Jacq., Leucaena leucocephala (Lamk.) De Wit., Antiaris africana Engl., Anogeissus leiocarpus (DC.) Guill.\&Perr., Spondias mombin L., Pycnanthus angolensis (Welw.) Warb., Lecanodiscus cupanioides Ex. Benth., and Ficus exasperata Vahl, having association distances of $6.3 \mathrm{~m}, 6.5 \mathrm{~m}, 6.9 \mathrm{~m}, 7.1$ $\mathrm{m}, 7.2 \mathrm{~m}, 7.5 \mathrm{~m}, 8.3 \mathrm{~m}, 8.5 \mathrm{~m}, 9.4 \mathrm{~m}$ and 10.5 $\mathrm{m}$ respectively. On the other hand, tree species that have the weakest association with $M$. excelsa are Enterolobium cyclocarpum (Jacq.) Griseb (29.8 m), Petrophorum pterocapum (DC.) K. Heyne (29.3 m), Bosqueia angolensis Ficalho (28.4 m), Albizia zygia (DC.) J. F. Macbr (26.6 $\mathrm{m})$, Cascabela thevetia (L.) Lippold (26.4 m) and Lannea welwitschii (Hiern) Engl.(25.3 m). Based on the frequency and percentage of occurrence of the species, $N$. laevis has the highest population of 12 individual trees, representing $14.5 \%$ of the total species population. This is followed by $A$. africana and $B$. sapida, having a population of 7 individual trees (8.4\%) each. Tree species such as Afzelia bella Harms. Caes., Anogeissus leiocarpus (DC.) Guill.\&Perr., Ceiba petandra L., Entandrophragma cylindricum, Enterolobium cyclocarpum, Ficus mucuso Welw. ex Ficalho., Holarrhena floribunda (G. Don) Durand \& Schinz., Lannea welwitschii (Hiern) Engl., Leucaena leucocephala, Petrophorum pterocapum, Plumera rubra L., Pycnanthus angolensis, Rauvolfia vomitoria Afzel. Ex Spreng., Thevetia nerrifolia Juss. Ex Steud. And Trichilia heudelotii Planch. exOliv. are represented with a single tree each accounted for just $1.2 \%$ of the total population.

The percentage distribution of trees into families (Figure 2) shows that Leguminosae $(16.1 \%)$ is the highest represented family. This is closely followed by Apocynaceae (12.9\%). Next to Apocynaceae are Fabaceae, Meliaceae and Moraceae having the same representation 
TABLE 1. Tree species associated with $M$. excelsa

\begin{tabular}{|c|c|c|c|c|c|}
\hline Tree species & $\begin{array}{l}\text { Common/Local } \\
\text { Name }\end{array}$ & Family & $\begin{array}{c}\text { Average } \\
\text { distance } \\
(\mathrm{m})\end{array}$ & $\begin{array}{c}\text { Frequency } \\
\text { (n) }\end{array}$ & $\begin{array}{c}\text { Proportion } \\
(\%)\end{array}$ \\
\hline Afzelia bella Harms. Caes. & Apa & Leguminosae & 22.3 & 1 & 1.2 \\
\hline Albizia lebbeck (L.) Benth. & Igbagbo & Leguminosae & 14.3 & 2 & 2.4 \\
\hline Albizia zygia (DC.) J. F. Macbr & Banabana & Leguminosae & 26.6 & 2 & 2.4 \\
\hline $\begin{array}{l}\text { Anogeissus leiocarpus (DC.) Guill. } \\
\& \text { Perr. }\end{array}$ & Axlewood & Loganiaceae & 7.5 & 1 & 1.2 \\
\hline Antiaris africana Engl. & False iroko & Polygonaceae & 7.2 & 7 & 8.4 \\
\hline Azadirachta indica A.Juss. & Neem tree & Meliaceae & 5.4 & 6 & 7.2 \\
\hline Blighia sapida K. Konig & Akeeaple & Sapindaceae & 11.7 & 7 & 8.4 \\
\hline Bombax buonopozense P. Beauv. & Red cotton tree & Bombacaceae & 15.1 & 2 & 2.4 \\
\hline Bosqueia angolensis Ficalho & Saworo & Moraceae & 28.4 & 4 & 4.8 \\
\hline Ceiba petandra L. & Kapok & Bombacaceae & 15.4 & 1 & 1.2 \\
\hline $\begin{array}{l}\text { Daniella ogea (Harms) Rolfa ex } \\
\text { Holland. }\end{array}$ & Balsam tree & Leguminosae & 17.6 & 3 & 3.6 \\
\hline Elaeis guineensis Jacq. & Oil Palm & Palmae & 6.9 & 6 & 7.2 \\
\hline $\begin{array}{l}\text { Entandrophragma cylindricum } \\
\text { (Sprague) Sprague }\end{array}$ & Cedar mahogany & Meliaceae & 6.3 & 1 & 1.2 \\
\hline $\begin{array}{l}\text { Enterolobium cyclocarpum (Jacq.) } \\
\text { Griseb }\end{array}$ & Ear pod & Leguminosae & 29.8 & 1 & 1.2 \\
\hline Ficus exasperata Vahl & Sand paper tree & Moraceae & 10.5 & 2 & 2.4 \\
\hline Ficus mucuso Welw. ex Ficalho. & Fig & Moraceae & 11.0 & 1 & 1.2 \\
\hline Gliricidia sepium (Jacq.) Kunth & Gliricidia & Fabaceae & 17.9 & 5 & 6.0 \\
\hline $\begin{array}{l}\text { Holarrhena floribunda (G. Don) } \\
\text { Durand \& Schinz. }\end{array}$ & False rubber tree & Apocynaceae & 16.2 & 1 & 1.2 \\
\hline Lannea welwitschii (Hiern) Engl. & Muumbu & Anacardiaceae & 25.3 & 1 & 1.2 \\
\hline Lecanodiscus cupanioides Ex. Benth. & Akika & Sapindaceae & 9.4 & 2 & 2.4 \\
\hline $\begin{array}{l}\text { Leucaena leucocephala (Lamk.) De } \\
\text { Wit. }\end{array}$ & Jumpy bean & Fabaceae & 7.1 & 1 & 1.2 \\
\hline Morinda lucida Benth & Oruwo & Rubiaceae & 19.7 & 2 & 2.4 \\
\hline $\begin{array}{l}\text { Newbouldia laevis (P. Beauv.) Seem. } \\
\text { ex Bureau }\end{array}$ & Tree of life & Bignoniaceae & 20.1 & 12 & 14.5 \\
\hline $\begin{array}{l}\text { Petrophorum pterocapum (DC.) K. } \\
\text { Heyne }\end{array}$ & Rain tree & Fabaceae & 29.3 & 1 & 1.2 \\
\hline Plumera rubra L. & Frangipani & Apocynaceae & 25.8 & 1 & 1.2 \\
\hline $\begin{array}{l}\text { Pycnanthus angolensis (Welw.) } \\
\text { Warb. }\end{array}$ & African nutmeg & Myristicaceae & 8.5 & 1 & 1.2 \\
\hline $\begin{array}{l}\text { Rauvolfia vomitoria Afzel. ex } \\
\text { Spreng. }\end{array}$ & Swizzler stick & Apocynaceae & 18.5 & 1 & 1.2 \\
\hline Spondias mombin L. & Hog plum & Anacardiaceae & 8.3 & 4 & 4.8 \\
\hline Sterculia tragacantha Lindl. & Star chesnut & Sterculiaceae & 13.4 & 2 & 2.4 \\
\hline Thevetia nerrifolia Juss. ex Steud. & Bush milk & Apocynaceae & 26.4 & 1 & 1.2 \\
\hline Trichilia heudelotii . Ex Oliv. & Rere & Meliaceae & 6.5 & 1 & 1.2 \\
\hline
\end{tabular}


of $9.7 \%$. The families with the lowest representation of 3.2\% include Bignoniaceae, Loganiaceae, Myristicaceae, Palmae, Polygonaceae, Rubiaceae and Sterculiaceae.

\section{The Distribution of $M$. excelsa and Sex Ratio}

The results show that a larger population (32 stands), which accounted for $65.3 \%$ of $M$. excelsa is located in the forest in the residential area of the study location, while 17 stands (34.7\%) are distributed within the forest around the school area. Chi-square result (Table 2) shows that the sex distribution of the species does not significantly depend on the location. The relative number of males (11) in the school area is lower than that of the relative number of males in the residential area (15). Similarly, the relative number of females in the school area (6) is lower compared to the number of females in residential area (17). The overall number of males (26) is slightly larger than females (23), resulting with approximate sex ratio of 1:1.

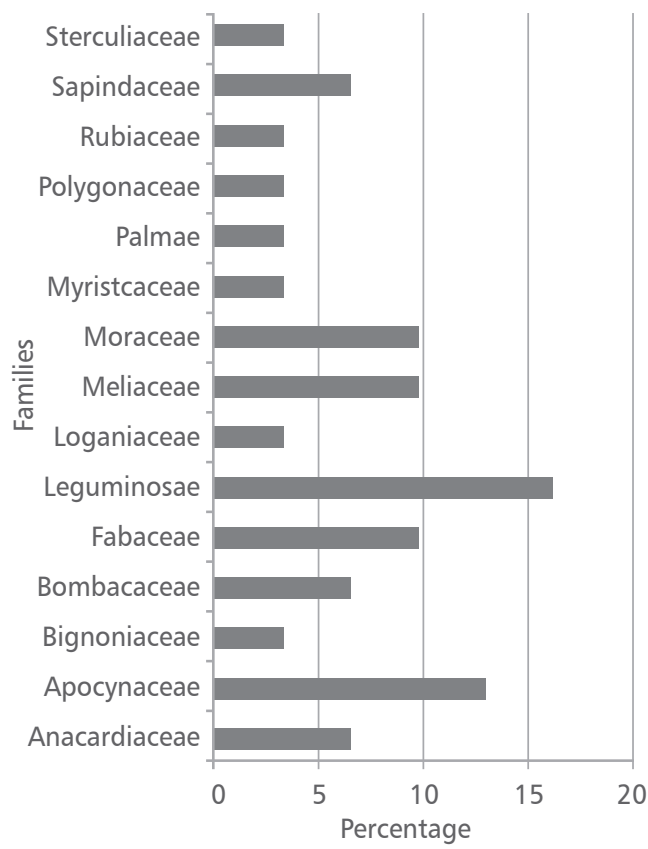

FIGURE 2. The distribution of the M. excelsa's associates by family
TABLE 2. The effect of location on sex distribution of $M$. excelsa

\begin{tabular}{|c|c|c|c|c|c|}
\hline \multirow{2}{*}{ Sex } & \multicolumn{2}{|c|}{ Location } & \multirow{2}{*}{$\begin{array}{l}\text { Chi- } \\
\text { square } \\
\text { value }\end{array}$} & \multirow{2}{*}{ df } & \multirow{2}{*}{ p-value } \\
\hline & School & Resident & & & \\
\hline Male & 11 & 15 & 1.417 & 1 & $0.234 \mathrm{~ns}$ \\
\hline Female & 6 & 17 & & & \\
\hline Total & 17 & 32 & & & \\
\hline
\end{tabular}

\section{DISCUSSION}

This study's findings support assertion by Garrity [7] claiming that a woody tree species is justified to be used for multiple tree agroforestry if it supports the existence of other woody species around its niche. Hence, the observed associates of $M$. excelsa in this study indicate its potential for agroforestry uses. In addition, the diversity of the $M$. excelsa associates encountered in this study appeared to be in agreement with White [18], who found that tree of similar evolutionary history tend to be adapted to a peculiar location and niche. For instance, the best three associates (i.e. A. indica, E. cylindricum and T. heudelotii ) discovered in this study are in the same family of Meliaceae with $M$. excelsa. This is in agreement with the work of Oni and Hall [19] on Parkia biglobosa. These authors discovered that similar tree species share similar edaphic and other growth requirements.

Having tree species like $E$. guineensis, $E$. cylindricum, $L$. leucocephala and $P$. angolensis as associates of $M$. excelsa additionally confirms its potential for agroforestry purpose. This is based on the fact that the named species are economically important tree species used on many occasions to support human livelihoods, especially in rural areas. For example, all parts of $E$. guineensis are used for various purposes [17]. According to Neupane and Thapa [5], L. leucocephala is one the most important tropical tree species and has been variously employed to improve soil fertility in the tropics through alley agroforestry practice. 
The differences in the population of the associated trees in this study may be attributed to the aftermath effect of human impacts on the environment and the identified economic importance of the species. For instance, $N$. laevis, $A$. africana and Blighia sapida, which had the highest population among the associates, have been previously identified as less known species [19] and therefore, less prone to exploitation by humans. Tree species such as $P$. rubra, $R$. vomitoria and $T$. nerrifolia, which are also less known species [19] are also less represented, which may be due to the fact that their regeneration ability is low. The family distribution of the tree associates of $M$. excelsa recorded in this study supports the previous study [20] claiming that Leguminosae is among the most numerous tree species families.

The least disturbed stands had a greater proportion of female trees. This is probably because female iroko tree (Figure 1, left) have better quality trunks in terms of physiognomy and length than the male counterpart (Figure 1 , right), which can be easily converted to sawn timber for utilization purposes.

The unbiased ratio of the male and female population of $M$. excelsa recorded in this study agrees with Ndakidemi and Ndakidemi [21]. They reported that balancing the number of male and female in a dioecious plant is very important for the rapid regeneration in agroforestry system. This fact coupled with others such as the presence of matured mother trees, the reduced logging of the subject tree and the absence of significant ecological threat may have been the reasons why the population of M. excelsa's sex is unbiased in the University of Ibadan compared to the biased population in Ibadan metropolis as reported by a previous study [15].

\section{CONCLUSION}

This study showed that $M$. excelsa has the potential of being used for multi-species agroforestry projects. This conclusion is based on the association of iroko with a large number of tree species. The associated tree species also happened to be economic trees upon which the users can depend for livelihood and sustenance. The results of this study revealed that Azadirachta indica, E. cylindricum, T. heudelotii and $E$. guineensis can be combined with iroko in multi-tree species agroforestry. This is based on the fact that these tree species have been found to grow naturally where iroko survived and are also in the same family with iroko. Hence, their edaphic requirements are similar to that of iroko, which will favour the growth of the adjoining agricultural crops as well as the entire agroforestry system. The findings revealed that evolutionary relationship has a key role to play in determining the phytosociology of a tree species population.

The population size of iroko is under strong influence of human activities. The number of female trees is under larger pressure due to better quality timber.

\section{REFERENCES}

1. COOPER PJM, LEAKEY RRB, RAO MR, REYNOLDS L 1996 Agroforestry and the mitigation of land degradation in the humid and sub-humid tropics of Africa. Exp Agr 32 (3): 235-290. DOI: http:// dx.doi.org/10.1017/S0014479700026223

2. SANCHEZ PA 1995 Science in agroforestry. Agroforest Syst 30 (1): 5-55. DOI: http://dx.doi. org/10.1007/BF00708912
3. FRANZEL S, COOPER J, DENNING GL 2001Scaling up the benefits of agroforestry research: Lessons learned and research challenges. Development in Practice 11 (4): 524-534. DOI: http://dx.doi. org/10.1080/09614520120066792

4. KANG BT, AKINNIFESI FK 2000 Agroforestry as alternative land-use production system for the tropics. Nat Resour Forum 24 (2): 137-151. DOI: http://dx.doi.org/10.1111/i.1477-8947.2000. tb00938.x 
5. NEUPANE RP, THAPA GB 2001 Impact of agroforestry intervention on soil fertility and farm income under the subsistence farming system of the middle hills, Nepal. Agr Ecosyst Environ 84 (2): 157-167. DOI: http://dx.doi.org/10.1016/S01678809(00)00203-6

6. NEUPANE RP, SHARMA KR, THAPA GB 2002 Adoption of agroforestry in the hills of Nepal: a logistic regression analysis. Agr Syst 72(3): 177-196. DOI: http://dx.doi.org/10.1016/S0308521X(01)00066-X

7. GARRITY D 2006 Science-based agroforestry and the achievement of the Millenium Development Goals. In: Garrity D, Okono A, Grayson M, Parrott $\mathrm{S}$ (eds) World Agroforestry into the Future. World Agroforestry Centre, Nairobi, Kenya, pp 3-8

8. RACE D 2009 Adoption of agroforestry in Australia. In: Nuberg I, Reid R, George BH (eds) Agroforestry for natural resource management. CSIRO Publishing, Collingwood, VIC, Australia, pp 323-340

9. THE WORLD BANK 2004 Sustaining Forests - A Development Strategy. The World Bank, Washington, DC, USA, 80 p. URL: http:// siteresources.worldbank.org/INTFORESTS/

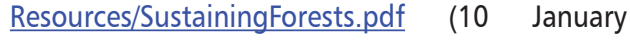
2015)

10. PISANELLI A, POOLE J, FRANZEL S 2008 The adoption of improved tree fallows in Western Kenya: farmer practices, knowledge and perception. Forests, Trees and Livelihoods 18 (3): 233-252. DOI: http://dx.doi.org/10.1080/1472802 8.2008.9752634

11. SILESHI G, MAFONGOYA PL 2006 Variation in macrofaunal communities under contrasting land-use systems in eastern Zambia. App/ Soil Ecol 33 (1): 49-60. DOI: http://dx.doi.org/10.1016/j. apsoil.2005.09.003

12. SILESHI G, MATAKALA PW, AKINNIFESI FK, AJAYI OC 2007 Environmental services of agroforestry in Southern Africa: lessons, challenges and future directions. World Agroforestry Centre.
13. MITTI JM, JACQUET DE, HAVESKERCKE C, KABWE $G$, KATANGA $R$, MWENYE D, MATARIRANO L, NYIRONGO J 2005 Scaling out agroforestry: experiences from Southern Africa. The Harvester 2 (3): 17-18

14. NWOBOSHI LC 1982 Tropical Silviculture: Principles and Techniques. Ibadan University Press, Ibadan, Nigeria, $333 \mathrm{p}$

15. BOROKINI TI, ONEFELI AO, BABALOLA FD 2013 Inventory analysis of Milicia excelsa (Welw C.C. Berg.) in Ibadan (Ibadan Metropolis and University of Ibadan), Nigeria. Journal of Plant studies 2 (1): 97-109. DOI: http://dx.doi.org/10.5539/jps. v2n1p97

16. ZUBAIR M, GARFORTH C 2006 Farm level tree planting in Pakistan: The role of farmers' perceptions and attitudes. Agroforest Syst 66 (3): 217-229. DOI: http://dx.doi.org/10.1007/s10457005-8846-Z

17. OWUSU DY 1993 Farm-based agroforestry: four years of experience in Ghana. Agroforestry Today 5 (1): 8-9

18. SABITTI EN, COBBINA J 1992 Parkia biglobosa: a potential multipurpose fodder in tree legume in West Africa. International Tree Crop Journal 7 (3): 113-139. DOI: http://dx.doi.org/10.1080/0143569 8.1992.9752911

19. ONI PI, HALL JB 2010 The phytosociology and ecological niche of $P$. biglobosa (Jacq) Benth: Implications for conservation and management. Nigerian Journal of Science 44: 17-28

20. WINSOR MP 2000 Species, Demes and the Omega Taxonomy: Gilmour and The New Systematic. Biol Philos 15 (3): 349-388. DOI: http://dx.doi. org/10.1023/A:1006774217770

21. NDAKIDEMI CF, NDAKIDEMI PA 2013 An investigation of natural regeneration trend of Brachylaena huillensisin Bombo West Forest Reserve, Tanga, Tanzania. American Journal of Research Communication 1 (12): 138-151 